\title{
ЦЕРКОВНО-ПОЛИТИЧЕСКИЙ СЕПАРАТИЗМ В ПРЕДЕЛАХ ЮГО-ВОСТОЧНОЙ ВИЗАНТИИ: ПУБЛИЧНО-ПРАВОВОЙ КОНТЕКСТ (553-564 ГОДЫ)
}

Целью нашей статьи является исследование политической институционализации первых форм канонического «сепаратизма» внутри Христианской церкви Восточной Римской империи. Таковыми были:

1) попытка объединения антиохийского и ктесифонского несторианства в 540-х - 560-х гг.;

2) провозглашение т. н. «Александрийского Папства» в 560-х - 570-х гг.

Соответственно, мы обратим внимание на общий политический фон «Пятидесятилетнего мирного договора», закончившего войну Ирана и Византии в 562 г. [8, с. $61 ; 14$, с. 538-541]. Ведь в то время, когда 562-й год принес Восточной Римской империи (Византии) долгожданный мир с Новоперсидским царством (Эраншахром), император Юстиниан Великий (527-565 гг.), по своей личной инициативе, предпринял масштабную попытку установить полноценное религиозное согласие в Восточноримском государстве [6, с. 465-469; 19, сс. 280-282; 23, с. 101].

Решения Пятого Константинопольского Собора (553 г.) [6], созванного Юстинианом Великим, хотя и стали основанием для формализации административнополитического влияния ортодоксального Константинопольского патриархата [об «ортодоксии» и «ересях»: 4, с. 140], анафематствовав германцев-ариан, сирийских несториан и египетских монофизитов, но не установили стабильных отношений внутри иерархии самой ортодоксальной церкви [6, с. 454-458, 465, 473-474].

С одной стороны, де-юре ортодоксальные александрийцы продолжали исповедовать самое чистое монофизитство, отказываясь признавать дуализм природы Иисуса Христа [6, с. 465; 18; 23, с. 101-110].

$\mathrm{C}$ другой стороны, несторианство, поддерживаемое оппозиционным Юстиниану монофизитским движением из Египта и Армении, а также Хосровом Ануширваном из Ктесифона [19, с. 281], оставалось важнейшим христианским течением в пограничной с Ираном Сирии [см. общий контекст: 5, с. 46-57; 16].

Если Каппадокия, Кипр и Киликия были оплотом ортодоксального христианства, то все земли к юго-востоку от сирийской Эдессы превратились в самостоятельную и неуправляемую Константинополем религиозно-политическую единицу [2; $3 ; 10 ; 16 ; 17$; особенно см.: 23, с. 101-110].

Разгром Хосровом Ануширваном Антиохии в 540 г. [9, с. 253] ударил по ортодоксальной общине сирийской столицы и вернул епископальную власть в диоцезе сторонникам несторианства. Тесные связи сирийских несториан с Ктесифоном [5, с. $51 ; 19$, с. 281] позволяли отдельным иерархам восстановленного Антиохийского диоцеза лелеять честолюбивую мечту [20, с. 81-90] об инкорпорации всей 
канонической территории Ктесифонского патриархата, созданного в 499 г. персидским шахиншахом Кавадом [22]. Возможным основанием для такой юридической процедуры несторианским теоретикам представлялась аннексия Сирии Эраншахром. Понятно, что абсолютное предательство Константинополя сирийскими клириками сдерживала только предполагаемая «второстепенность» их церковной иерархии в условиях персидского политического контроля.

Иерусалимский патриархат тоже вынужденно терпел присутствие большого количества монофизитов и несториан, поскольку географически служил контактной территорией для всех еретических движений. Несмотря на жестокую взаимную вражду V в., погубившую влияние еретических партий в Константинополе, несториане и монофизиты нашли неканонические (т. е. политические) возможности для перемирия в 540-550-х гг. VI в. Они были слабы в Аравии и Иудее, но именно там располагали монастырскими обителями и постоялыми дворами, где проводили тайные собрания и «богословские конференции», ставившие своей целью подрыв влияния и власти восточноримского императора, направленный на формирование независимых от Константинополя церковных диоцезов [6, с. 475-478; 20 , с. $81-100 ; 23$, с. $101-110]$.

В первую очередь заговорщики желали уничтожить власть Константинопольского патриархата, лишить его арбитражных и прочих канонических процессуальных функций, подорвать политический авторитет и юрисдикционные полномочия патриарха. Опорочить патриархат и обвинить самих константинопольцев в ереси самая излюбленная тактика монофизитов и несториан [13]. Лишь после падения Константинопольского патриархата, его унижения и политического разгрома покровительствовавшей ему императорской власти еретики считали необходимым вступать в христологические споры друг с другом [20; 22]. В этом шатком «согласии» монофизиты и несториане эпохи Юстиниана Великого (527-565 гг.) получали сочувствие и поддержку иранского правителя Хосрова Ануширвана (531-579 гг.) [15]. Координировать борьбу византийских еретиков против государственных устоев был назначен Ктесифонский несторианский патриархат [5, с. 51], который, благодаря разветвленной сети шпионов, стал наиболее приближенной к особе шахиншаха религиозной организацией Новоперсидского царства ${ }^{1}$.

Переключившись с переписывания "Авесты» на христологические дискуссии внутри соседней Византии [14; 22], Хосров Ануширван принял предложение Юстиниана Великого прислать несторианских богословов для теологического диспута, состоявшегося в Константинополе в 564 г. В частности, в обсуждении предложенных Юстинианом догматов о нетленности тела Христа принимали участие ктесифонский несторианский патриарх Мар Иосиф I (552-566 гг.) и теолог Эзекбиэль (будущий ктесифонский патриарх в 566-581 гг.). После проведения консультаций с представителями александрийской и антиохийской патриархий, константинопольцами, испанцами, ливийцами и представителями Римского Папства пронесторианские богословы покинули данное совещание и объявили Юстиниана «кло-

${ }^{1}$ Де-факто при Хосрове Ануширване (531-579) Ктесифонский патриархат выполнял функции религиозно-идеологического центра западной политики Эраншахра [22]. 
акой всех ересей целой Ойкумены». При этом, мы предполагаем, что они также поссорились с египетскими монофизитами и сирийскими несторианами, считавшимися до того момента ситуативными союзниками Персии. Что касается ссоры персидских христиан с сирийскими, то здесь, очевидно, необходимо определить причиной неспособность точно определить каноническую принадлежность Сирии и Месопотамии. И антиохийские, и ктесифонские иерархи, независимо от ортодоксальных или еретических симпатий, рассматривали Ближний Восток как свою каноническую собственность $[2 ; 3 ; 6 ; 14 ; 21 ; 22]$.

Таким образом, попытка примирения, инициированная Юстинианом Великим, вновь окончилась тактической неудачей. Антивизантийская пропаганда только усилилась, исходя из уст настоятелей Ктесифонской церкви [22]. Однако стратегической победой Юстиниана в последние годы правления (562-565 гг.) стало разобщение несториан-антиохийцев и несториан Персии. Поняв, что персидские «назареи» не пожелают вернуться в состав Антиохийской патриархии, даже в случае оккупации Антиохии шахиншахом, втайне сочувствовавшие ересям иерархи Антиохийского диоцеза отвернулись от персов. В дальнейшем, приобретая сообщников в Сирии и Месопотамии, персам приходилось чаще использовать деньги и шантаж, нежели взывать к конфессиональному патриотизму или религиозной идентичности. Юстиниан Великий сумел склонить антиохийцев, несмотря на повсеместную оппозицию Сирии официальному Константинополю, к плодотворному сотрудничеству в борьбе с монофизитствующими египетскими еретиками. Главным для антиохийцев, конечно же, оставалось императорское признание персидских земель (вплоть до Афганистана и Индии) канонической территорией Антиохийского патриархата, чего ни в коем случае нельзя было ожидать от персидского шахиншаха $\left[19\right.$, с. $277-281 ; 20$, с. 81-100; 23, с. 101-110] ${ }^{2}$. Предполагаем, что антиохийцам Юстинианом было также обещано добиться признания третьего места для их патриархата в ортодоксальном диптихе экклезий. Такой шаг явно способствовал бы ослаблению александрийской оппозиции.

В Александрийском диоцезе все было гораздо сложнее. «Мирные» инициативы Юстиниана и внутренний кризис несторианства отозвались в Египте серьезными административными проблемами. В частности, состоялось фактическое разделение единого Александрийского патриархата на две конкурирующие организации [20, с. 81-100].

Все лояльные к Юстиниану подданные (преимущественно эллины) открыто вошли в состав обновленного, после череды реформ 538-553 гг., Александрийского патриархата, признавшего решения Четвертого Халкидонского Вселенского Собора (451 г.). Впрочем, прихожане этого патриархата к 565 г. составляли лишь около 300000 человек (чуть более $5 \%$ населения провинции Египет). Остальные пять с половиной миллионов подданных Константинополя, проживавшие в Египте, открыто поддержали Александрийский патриархат монофизитского

\footnotetext{
${ }^{2}$ Максимум, чего сирийцы могли бы добиться в условиях персидской аннексии, так это создания вместо патриархата какой-либо "Антиохийской митрополии», наподобие Мервской.
} 
толка (преимущественно копты - наследники древних египтян [1, с. 165], а также смешанное население македоно-греко-египетского происхождения и ливийские племена) [20;21;23].

«Альтернативный» монофизитский патриархат возглавлялся патриархом Феодосием I (535-537 гг.) вплоть до 566 г. лишь номинально, поскольку тот находился в пожизненном заточении в Новом Риме. Реальное руководство альтернативным патриархатом осуществляли агенты Хосрова Ануширвана, использовавшие патриарха Феодосия как символ. Именно они подготовили монофизитам патриаршего преемника Петра IV (575-578 гг.). Начиная с Петра, Александрийский патриархат монофизитов, признаваемый «законной церковью» абсолютным большинством египтян, провозгласил себя «Александрийскил Папствол и Патриархатол Престола Святого Марка в Африке и на Ближнем Востоке» [21; 22; 23, об идеологических принципах папства см.: 7, с. 64].

Именно из-за массовости движения власти Восточной Римской империи не смогли разгромить еретическое сообщество («экклезия») монофизитов-коптов $[3 ; 10 ; 13 ; 16 ; 17]$. Её многочисленность и агрессивность вызывала неприкрытую боязнь восстания. Чиновники из константинопольского императорского дворца прикладывали много усилий для дипломатического умиротворения египетских монофизитов. Конечно же, Юстиниан Великий и его преемники понимали, что финансовую мощь копты черпали из персидских источников. Однако Юстиниан понимал и другое: уничтожить всех коптских иерархов означало дать старт кровопролитной гражданской войне в Египте - стране, являвшейся общеимперским поставщиком хлеба и всех продуктов первой необходимости $[10 ; 11 ; 12 ; 17]$. Кроме того, в конфликт немедленно вмешался бы иранский шахиншах Хосров Ануширван, пытаясь «восстановить египетские владения предков-Ахеменидов» . Юстиниан, в этой связи, избрал единственно возможную политическую тактику выжидать (эта тактика ударила в спину византийцам в начале VII в.). Впрочем, других вариантов решить египетский кризис, не проливая крови сограждан, по нашему глубокому убеждению, не существовало. Однако если бы Юстиниан Великий хотя бы отдаленно предчувствовал начало исламской экспансии (развернулась в 629-636 гг.), то, можем быть уверенными, он, безусловно, организовал бы уничтожение египетских монофизитов - главных государственных изменников (с позиций рилского публичного права, конечно же) не только в шестом веке, но и, наверняка, в целом первом тысячелетии после Рождества Христова.

\section{Лumepamypa}

1. Авдиев В. История Древнего Востока. 2-е изд., перераб. и дополн. Москва : Государственное издательство политической литературы, 1953. 760 с.

2. Аверинцев С. От берегов Босфора до берегов Евфрата: литературное творчество сирийцев, коптов и ромеев в I тысячелетии н. э. От берегов Босфора до берегов Евфрата. Москва : Наука, 1987. С. 5-52.

3. Васильев А. История Византийской империи. Время до Крестовых походов (до 1081 г.). Санкт-Петербург : Алетейя, 1998. 514 с.

4. Верещагина Н. Курс лекций по истории мировой культуры и искусства. Одесса : Астропринт, 2013. $268 \mathrm{c}$.

5. Гумилев Л. В поисках вымышленного царства. Санкт-Петербург : Азбука-классика, 2014. 480 c. 
6. Дворкин Александр. Очерки по истории Вселенской православной церкви. Нижний Новгород : Христианская библиотека, 2016. 1024 с.

7. Ерде Петер. Церковне конституційне право. Львів : Свічадо, 1998. 156 с.

8. Курбатов Г. История Византии (От античности к феодализму). Москва : Высшая школа, 1984. 207 c.

9. Курбатов Г. Ранневизантийские портреты: К истории общественно-политической мысли. Ленинград : Издательство Ленинградского университета, 1991. 272 с.

10. Люттвак Эдвард Н. Стратегия Византийской империи. Пер. с англ. А. Коваля. Москва : Русский фонд содействия образованию и науке, 2016. 664 с.

11. Мельник В. Византия, германцы и славяне у истоков международной правосубъектности государств: римское юридическое наследие и проблема исторического неравенства возможностей. Аннали юридичної історї̈. 2017. Т. 1. № 2. С. 59-92.

12. Мельник В. Смена эпох : очерк формирования римско-византийской доктрины международного права (III-VI вв.). Аннали юридичної історї. Т. 2. № № 1-2. Січень - червень 2018. Випуск« «сторія та географія середньовічного права». С. 63-108.

13. Миринейский Агафий. О царствовании Юстиниана. Пер., ст. и примеч. М. Левченко. Москва ; Ленинград : Изд-во АН СССР, 1953. 221 с.

14. Мишин Д. Хосров I Ануширван (531-579), его эпоха и его жизнеописание и поучение в истории Мискавейха. Москва : Институт востоковедения РАН, 2014. 696 с.

15. Периханян А. Общество и право Ирана в парфянский и сасанидский периоды. Москва : Наука, 1983. $384 \mathrm{c}$.

16. Пигулевская Н. Византия и Иран на рубеже VI-VII вв. / отв. ред. В. Струве. Труды института востоковедения. Москва ; Ленинград : Издательство Академии наук СCCP, 1946. T. XLVI. 291 с.

17. Хизер Питер. Восстановление Римской империи. Реформаторы Церкви и претенденты на власть. Москва : Центрполиграф, 2015. 575 с.

18. Хосроев А. Александрийское христианство по данным текстов из Наг Хаммади. Москва : Наука, $1991.276 \mathrm{c.}$

19. Che Jayoung. The Political and Social Conflict between Orthodox Christianity (Constantinople and Rome) and Eastern Monophysitism. Athens Journal of History. October 2015. Vol. 1. Is. 4. P. 267-288. DOI: $10.30958 /$ ajhis.1-4-2.

20. Hardy Edward Rochie. The Patriarchate of Alexandria: A Study in National Christianity. Church History. 1946. Vol. 15. Is. 2. P. 81-100. DOI: $10.2307 / 3160398$.

21. Hardy Edward Rochie. Christian Egypt: Church and People, Christianity and Nationalism in the Patriarchate of Alexandria. New York : Oxford University Press, 1952. IX + 241 p.

22. Moffett Samuel Hugh. A History of Christianity in Asia. Volume 1: Beginnings to 1500. New York : HarperCollins Publishers, 1998. 560 p.

23. Sabo Theodore. From Monophysitism to Nestorianism: AD 431-681. Newcastle upon Tyne : Cambridge Scholars Publishing, 2018. IX + 135 p.

\section{Аннотация}

Мельник В. М. Церковно-политический сепаратизм в пределах юго-восточной Византии: публично-правовой контекст (553-564 годы). - Статья.

Статья посвящена исследованию публично-правовых формул несторианского и монофизитского сепаратизма в пределах сирийской и египетской провинций Восточной Римской империи. Для изложения материала избран поздний период правления императора Юстиниана Великого (527-565 годы), когда решения V Вселенского Собора (553 год) и Мирный договор с Ираном (562 год) позволили Константинопольскому патриархату приступить к восстановлению религиозного единства внутри Христианской церкви. Уступки императора Юстиниана не привели к желаемому результату и только накалили атмосферу во многокультурных сообществах Сирии и Египта. Например, в Сирии предпринимались попытки полного обособления Антиохийского патриархата от ортодоксальной (халкидонской) Византийской церкви. Главным сепаратистским движением здесь были несториане, проводившие политику сближения с быстро христианизирующимся Новоперсидским царством, управляемым династией Сасанидов. Впрочем, Юстиниану удалось остановить экспансию персидского несторианства в Сирии, поскольку Антиохийский патриархат испугался реальной перспективы поглощения Ктесифонским несторианским патриархатом. В свою очередь, Египет в 550-х годах стал ареной противостояния 
монофизитов и православных христиан. Несмотря на приверженность халкидонскому символу веры (451 год), Юстиниан был вынужден одобрить сосуществование двух параллельных христианских церквей в Египте - Александрийского ортодоксального патриархата и Александрийского папства коптов (монофизитского патриархата). Политический фон изложенных религиозных событий, а также императорские распоряжения и внутрицерковные решения (каноны), сопровождавшие поздний период царствования Юстиниана Великого, мы предлагаем считать важным предметом для дальнейших историко-юридических исследований. Во-первых, понимание взаимоотношений отдельных сепаратистских церквей и Константинополя позволяет глубже разобраться в политической теории византийской симфонии. Во-вторых, проанализированные споры и распри в ранней Византии позволяют сделать вывод о глубокой федерализации восточноримских общественных отношений. Режим lex foedus, предоставлявшийся варварам (германцы, славяне и кочевники) в течение всей эпохи позднеримского домината, укоренился в социальном мировоззрении и сформировал стереотип позитивного восприятия «децентрализированного государства» народными массами Восточной Римской империи.

Ключевые слова: Восточная Римская империя (Византия), ортодоксальное христианство (православие), церковный сепаратизм, церковные каноны, Константинопольский патриархат, Ктесифонский несторианский патриархат, Антиохийский патриархат, Александрийский патриархат, Александрийское папство.

\section{Анотація}

Мельник В. М. Церковно-політичний сепаратизм у межах південно-східної Візантії: публічноправовий контекст (553-564 роки). - Стаття.

Стаття присвячена дослідженню публічно-правових формул несторіанського та монофізитського сепаратизмів у межах сирійської і єгипетської провінцій Східної Римської імперії (Візантії). Для викладу матеріалу обрано пізній період правління імператора Юстиніана Великого (527-565 роки), коли рішення V Вселенського Собору (553 рік) і Мирний договір з Іраном (562 рік) дозволили Константинопольському патріархату розпочати відновлення релігійної єдності всередині Християнської церкви. Поступки імператора Юстиніана не привели до бажаних результатів і лише поглибили розкол між полікультурними спільнотами Сирії та Єгипту. Наприклад, у Сирії були спроби цілковитого відокремлення Антіохійського патріархату від ортодоксальної (Халкидонської) Візантійської церкви. Головним сепаратистським рухом Сирії стали несторіани, що проводили політику зближення із Сасанідським Іраном (на той момент у Персії швидко поширювався несторіанський варіант християнства). Утім, Юстиніану вдалось зупинити експансію перського несторіанства в Сирії, оскільки Антіохійський патріархат злякався реальної перспективи поглинання з боку Ктесифонського несторіанського патріархату. У свою чергу, Єгипет у 550 -х роках став ареною протистояння монофізитів і православних християн. Незважаючи на прихильність Халкидонському символу віри (451 рік), Юстиніан був змушений схвалити співіснування двох конкуруючих християнських церков - Олександрійського ортодоксального патріархату й Олександрійського коптського папства (монофізитський патріархат). Політичне тло викладених релігійних подій, а також імператорські розпорядження і внутрішньоцерковні рішення (канони), що супроводжували пізній період царювання Юстиніана Великого, ми пропонуємо вважати предметом для подальших історико-юридичних досліджень. По-перше, розуміння взаємин окремих сепаратистських церков і Константинополя дозволяє глибше розібратися в політичній теорії візантійської симфонії. По-друге, проаналізовані нами суперечки і чвари в ранній Візантії дозволяють зробити висновок про глибоку федералізацію східноримських суспільних відносин. Режим lex foedus, який надавався варварам (німці, слов'яни і кочівники) протягом усієї епохи пізньоримського домінату, укорінився в соціальному світогляді і сформував стереотип позитивного сприйняття «децентралізованої держави» з боку народних мас Східної Римської імперії.

Ключові слова: Східна Римська імперія (Візантія), ортодоксальне християнство (православ'я), церковний сепаратизм, церковні канони, Константинопольський патріархат, Ктесифонський несторіанський патріархат, Антіохійський патріархат, Александрійський патріархат, Александрійське папство.

\section{Summary}

Melnyk V. M. Church and political separatism within the Southeastern Byzantium: the context of public law (553-564). - Article.

The article is devoted to the study of the public-law formulas of Nestorian and Monophysite separatism within the Syrian and Egyptian provinces of the Eastern Roman Empire. For the presentation of the material, we choose the late period of the reign of Emperor Justinian the Great (527-565), when the Decisions of the V Ecumenical Council (553) and the Peace Treaty with Iran (562) allowed the Patriarchate of Con- 
stantinople to start restoring religious unity within the Christian Church. The concessions of the Emperor Justinian did not lead to the desired result and only inflamed the atmosphere in the multicultural communities of Syria and Egypt. For example, in Syria, were made attempts to completely separate the Antiochian Patriarchate from the Orthodox (Chalcedonian) Byzantine Church. The main separatist movement here were the Nestorians, who pursued a policy of rapprochement with the rapidly Christianizing New Persian kingdom ruled by the Sassanid dynasty. However, Justinian managed to stop the expansion of Persian Nestorianism in Syria, since the Antiochian Patriarchate was afraid of the real prospect of absorption by the Ctesiphonian Nestorian patriarchy. In turn, Egypt in the 550's became the arena of confrontation between Monophysites and Orthodox Christians. Despite adherence to the Chalcedonian Creed (451), Justinian was forced to approve of the coexistence of two parallel Christian churches in Egypt - the Alexandrian Orthodox Patriarchate and the Alexandrian Coptic Papacy (Monophysite Patriarchate). The political background of the stated religious events, as well as the imperial orders and internal church decisions (canons) that accompanied the late period of the reign of Justinian the Great, we propose to consider as important subject for further historical and legal research. First, an understanding of the relationship between the individual separatist churches and Constantinople, allows a deeper understanding of the political theory of the Byzantine symphony. Secondly, the analyzed disputes and feuds in early Byzantium allow us to draw a conclusion about the deep federalization of East Roman social relations. The lex foedus regime, afforded to the barbarians (Germans, Slavs and Nomads) throughout the dominate era, took root in the social worldview and formed a stereotype of a positive perception of the "decentralized state" by the populace of the Eastern Roman Empire.

Key words: Eastern Roman Empire (Byzantium), Orthodox Christianity (Orthodoxy), Church Separatism, Church Canons, Patriarchate of Constantinople, Ctesiphonian Nestorian Patriarchate, Patriarchate of Antioch, Patriarchate of Alexandria, Alexandrian Coptic Papacy. 